\title{
An Epistemological and Pattern Analysis of Empirical Data that Influences Emergency Loan Need Among Graduate Students
}

\section{Idemudia $\mathrm{EC}^{1 *}$ and Ferguson $\mathbf{R}^{2}$}

${ }^{1}$ Arkansas Tech University, College of Business, Russellville, USA

${ }^{2}$ Managing Director, Ethics Center, Texas Tech University, USA

\begin{abstract}
This analysis studies closely education affordability through the epistemology of emergency loan need that signals economic challenges on the horizon for domestic and international students seeking a post graduate credential at any cost. Prior studies have been very helpful; however, to the best of our knowledge there is not a comprehensive study that has investigated the comparison of small vs. large emergency student loans taken out by graduate students. Also, to the best of our knowledge and to date there are no studies that have investigated the patterns and relationships among ethnicity, gender, marital status, degree type, and college awarded for both small vs. large emergency loans. To fill the gaps in the literature, we conducted our research by collecting datasets from 335 graduate students enrolled in a large public university located in North America. Our data analysis provides strong indicators and evidence that both small and large emergency loan needs exist in a diverse spectrum of colleges, degree types, ethnicities, genders, ages, and marital statuses. Also, the regression analysis indicates that there is not a significant relationship between GPA and emergency loan needs for both small and large loans. We also, used data mining technique to investigate patters and relationships among ethnicity, gender, marital status, degree type, and college awarded for both small vs. large emergency loans. Our study contains vast research and managerial implications for both academia and top managements.
\end{abstract}

Keywords: Emergency loans; Graduate students; Loan and financial aid theory; Education economics; Loan payments; Economic growth; Academic performance; Graduate school; Patterns; Generalized linear model; Web graph

\section{Introduction}

Emergency loan need signal that domestic and international students may suffer sufficient economic distress due to shifts in the global economy and prohibitive historical social factors. Korn [1] reports that most low income students who pursue degrees fail to make it to graduation. This contributes to deepening economic calamity noted by Frolich [2] in the study that examined the earnings gap between black and white families. Debt among domestic and international students is an incurable ailment: a quagmire more tangled than the challenges of health insurance, tuition, and technology and resource fees [3-5]. The loan and financial aid theory assesses the economics of the debt service revenue bubble that impacts participation in contributing to the expansion of goods and services productivity $[3,4]$. Whether students are completers or non- completers, emergency student loan need signals financial distress with a high likelihood that debt will restrict future participation in the market economy. Non-completers are burdened with self-acknowledgement that they accept less future earning power stepping out of their academic program. Korn [6] reports that more than half of public colleges in the U.S. are failing to bring in sufficient tuition revenue to keep up with inflation, and nearly as many private schools are facing a similar financial crisis. This assessment indicates that universities must borrow or pass cost directly to students in the form of tuition and/or fee increases. Domestic and international students must weigh the ethical quotient of acceptance against financial sustainability to completion, thus requiring a more careful analysis prior to enrollment in an academic institution.

Katherine Mangan [7] reports that enrollment dropped among non-traditional and part-time students, because the struggle to balance the competing demands of rising tuition cost and the responsibilities associated with jobs, college classes, daily expenses, and having a family were overwhelming. Students that vacate their efforts to achieve a degree are unable to alleviate the burdensome debt mired with a taxing responsibility equal to or greater than those who complete their program. Higher cost to attend universities continues to drive postsecondary degrees out of reach for many Americans [3-5]. Universities in the U.S. believe that Revenue Centered Budgeting (RCB)/Revenue Centered Management (RCM) may assist with cost reduction overtime. Lang [8] analyzes that RCB/RCM creates demand-driven buyers' markets. This indicates that market potential is not uniformly or universally distributed among academic programs. Depending on the program, $\mathrm{RCB} / \mathrm{RCM}$ influences are a detriment to students, because they compel humanities programs to increase fees to meet expenses while high demand STEM programs regulate their enrollment to generate a revenue surplus. Lang [8] continues to the effect that RCB/ RCM amounts to little more than an elaborate budgetary tautology. Affordability, as punctuated through emergency loan need, leaves students persisting in completing their studies while managing financial stress; they are subsequently unable to enjoy the benefit of their achievement. As a result of debt service responsibility, noted in the loan and financial aids theory model, students' contribution to the growth of the economy is stifled by the very opportunity that is supposed to be the gateway to wealth building $[3,4]$.

Though U.S. universities across disciplines continue to be the destination of choice for international students, Welitzkin [9] finds that Chinese solicitation for admissions into U.S. institutions has

*Corresponding author: Idemudia EC, Arkansas Tech University, College of Business, Russellville, USA, Tel: 479-880-4226; E mail: efoidemudia@hotmail.com

Received April 21, 2014; Accepted May 18, 2015; Published May 25, 2015

Citation: Idemudia EC, Ferguson R (2015) An Epistemological and Pattern Analysis of Empirical Data that Influences Emergency Loan Need Among Graduate Students. J Glob Econ 3: 143. doi:10.4172/2375-4389.1000143

Copyright: (C) 2015 Idemudia EC, et al. This is an open-access article distributed under the terms of the Creative Commons Attribution License, which permits unrestricted use, distribution, and reproduction in any medium, provided the original author and source are credited. 
dropped, especially among students seeking a graduate education. The drop may be accounted for by the increase in capacity of quality graduate programs and the high default rate on graduate student loans in China. This indicates that overtime fewer Chinese students will select a U.S. institution to study for a graduate degree. Emergency loan need signals the affordability challenge for domestic and international students. Yue [10] states that 28,000 students borrowed to finish their college education, and only about 6,000 received job offers. Since 2006, to assist students from poor families with education cost, the China Development Bank provided the U.S. equivalent of 427 million dollars in loans to assist more than 430,000 students. Though student loans are less than 10 years old in China, the bank reports only a 2 percent 2013 default rate. Debt adverse students from less wealthy households may opt out of getting a college degree due to economic uncertainty about employment upon degree completion. To retain the flow of students into U.S. universities, leadership at the state and federal levels of government must turn the tide on rising cost to remain an attractive option for domestic and international students. The indicators for emergency loan need have become an instrument used for survival in managing an unplanned crisis.

Dore [11] affirms that burdensome debt influences the conduct of banks in India. The problem of a high default rate exceeding 15\% in India curtails the willingness of banks to make education loans. Long term, this challenge may stagnate the expansion of the Indian economy, whereas, China may not be subject to the risk of economic stagnation due to the increased capacity of their universities to train post-secondary graduate students in-country. However, McMahon [12] reports that the burden of business borrowing prior to the global recession creates a debt service bubble that cools the Chinese economy. In addition, student loan defaults may contribute to the misery of an economic slowdown. Two emerging economies, China and India, risk forfeiting their most talented students due to challenges related to rising education cost. Swarup [13] poses that as a result of their inability to refuse education loans without sanction by a higher authority; Indian banks have been facing an escalating number of loan defaulters. So after a decade of low interest rates, the education loan scheme has been tightened. Adjustments in local practices clear a path that may generate more borrowing than less to enhance emergency loans needed to complete an academic program in the U.S. university system.

University leadership favors oligarchical tendencies where a handfull of non-venturesome administrators, staff, and faculty hold on to traditionalist practices that do a disservice in the management of taxpayer funds. Two under-valued items in this area, healthcare and living expenses, have an influence on emergency loan need. Supiano [14] reports that living expenses are under-discussed when it comes to college affordability. Universities prefer to present how they have regulated tuition and fees to make study affordable on their campus. Students are unaware of the tuition and fee differential when their academic program requires a course with a higher fee base to be taken in a different department. University leadership have demonstrated no initiative to flatten cost to assist this population of students. Universities are developing more multi- and inter-disciplinary degrees and discipline specific degrees require additional electives to achieve the credential, thus tuition and fees for a semester become a less stable and forecastable charge for students.

Second, the population of domestic students attending universities has been flat for approximately ten years. As the U.S. economy accelerates, the likelihood of a surge in domestic students populating campuses is unlikely. U.S. universities must recruit more students from emerging nations. This occurs at a time when the dollar is rising, putting stress on other economies for the cost of goods and services. Friedman [15] reports that the surging dollar benefits the U.S. and confounds central bankers by widening the gap between the U.S. economies and struggling countries in Europe and Asia. Though an excellent financial climate for the U.S., emerging economies' students have a different perspective when they consider the affordability of an education in an American university. These students carefully assess three cost factors: 1) out of state tuition; 2) living expenses; and 3) health insurance. If U.S. universities are unable to get ahead of these three costs to support sustainability among international students from emerging economies, a significant shift may be forthcoming in the recruit able population that can complete studies in the U.S. at their expense. As discussed, the high default rate on student loans does little to encourage bankers in China and India to invest in students that decide to study abroad. Emergency loan need among domestic and international students across disciplines signals that current student financial loan allocations fail to sufficiently meet high costs beyond tuition and fees.

Third, healthcare insurance and living expenses are unstable hidden costs that can generate excessive stress for domestic and international students. Students arriving in the U.S. from countries that have socialized healthcare have a difficult challenge with the cost of insurance here. As an example, less than ten years ago Indian students enjoyed an exchange rate of 42 to 45 Rupees on the dollar. Insurance has risen more than $30 \%$ in the same time frame, while the exchange rate exceeds 60 Rupees to the dollar. This example serves as an indicator to students in emerging nations that careful consideration of cost must be weighed when seeking an academic credential in the U.S. The recession slowed home construction across the country. More Americans moved into apartments, which has generated a surge in rent. Domestic and international students have an increased financial responsibility, due in part to the recession that initially influenced their decision to get an undergraduate and or graduate degree. Jamrisko and Kolet [16] report that the cost of obtaining a college degree has increased by 1,120 percent over the past 35 years. On average since 1978, tuition and fee increases are greater than $30 \%$ per annum. Emergency loan need signals that a reversal to dampen rising cost in education must be a part of future planning, so that domestic and international middle income students are not shut out of institutions due to affordability.

\section{Methodology}

The datasets for our study were collected from 335 graduate students who are currently enrolled in a large public university located in North America; and the characteristics of participants and subjects that participated in our study are shown in Table 1. The dataset for our study includes students who borrowed both small and large emergency loans. In our study, we refer to a small loan if the amount is less than or equal to five hundred dollars $(<=\$ 500)$; a large loan is identified if the amount is more than five hundred dollars $(>\$ 500)$. There were very few students who did not provide all the required information when completing the survey. The methodology we used in our study is survey methodology. Idemudia and Ferguson [3-5] argue that survey methodology is an appropriate methodology to investigate emergency loans and graduate students' academic performance. Some of the steps and procedures for completing the survey are as follows:

Students completed the emergency loan need forms by selfidentifying their financial dilemma.

Financial aid offers then review each request for emergency loan need by assessing the borrowing status under the department/ 


\begin{tabular}{|c|c|c|c|c|}
\hline & & & $\mathrm{N}$ & Percent \\
\hline & & & 1 & $.3 \%$ \\
\hline & & B (African American) & 30 & $9.0 \%$ \\
\hline & & $\mathrm{H}$ (Hispanic) & 35 & $10.4 \%$ \\
\hline & & I (American Indian) & 2 & $.6 \%$ \\
\hline & & M (Multiple) & 5 & $1.5 \%$ \\
\hline & Ethnicity & N (Non-Resident Alien) & 113 & $33.7 \%$ \\
\hline & & O (Other Pacific Islander) & 54 & $16.1 \%$ \\
\hline & & U (Unknown) & 9 & $2.7 \%$ \\
\hline & & W (White) & 81 & $24.2 \%$ \\
\hline & & X (Mexican American) & 5 & $1.5 \%$ \\
\hline & & Total & 335 & $100.0 \%$ \\
\hline & & Female & 119 & $35.5 \%$ \\
\hline & Gender & Male & 216 & $64.5 \%$ \\
\hline & & Total & 335 & $100.0 \%$ \\
\hline & & & 8 & $2.4 \%$ \\
\hline & & Married & 102 & $30.4 \%$ \\
\hline & $\begin{array}{l}\text { Marital } \\
\text { Status }\end{array}$ & Others & 82 & $24.5 \%$ \\
\hline & & Single & 143 & $42.7 \%$ \\
\hline & & Total & 335 & $100.0 \%$ \\
\hline Factor & & CERT (Certificate) & 12 & $3.6 \%$ \\
\hline & & DMA (Doctor of Music) & 9 & $2.7 \%$ \\
\hline & Degree & JD & 2 & $.6 \%$ \\
\hline & Type & Masters & 165 & $49.3 \%$ \\
\hline & & $\mathrm{PhD}$ & 147 & $43.9 \%$ \\
\hline & & Total & 335 & $100.0 \%$ \\
\hline & & Undecided & 11 & $3.3 \%$ \\
\hline & & $A$ and $S$ & 114 & $34.0 \%$ \\
\hline & & $A G$ and NR & 19 & $5.7 \%$ \\
\hline & & $\mathrm{ARCH}$ & 8 & $2.4 \%$ \\
\hline & & BUS & 24 & $7.2 \%$ \\
\hline & & EDU & 32 & $9.6 \%$ \\
\hline & College & ENG & 66 & $19.7 \%$ \\
\hline & Awarded & GRAD SCHOOL & 13 & $3.9 \%$ \\
\hline & & Graduate School & 1 & $.3 \%$ \\
\hline & & HUM SCl & 20 & $6.0 \%$ \\
\hline & & LAW & 2 & $.6 \%$ \\
\hline & & MASS COMM & 1 & $.3 \%$ \\
\hline & & VPA & 24 & $7.2 \%$ \\
\hline & & Total & 335 & $100.0 \%$ \\
\hline
\end{tabular}

Note: The sample size is 335 .

College Awarded legend: A and S: College of Arts and Sciences; AG and NR: College of Agriculture; ARCH: College of Architecture; BUS: College of Business; EDU: College of Education; ENG: College of Engineering; GRAD SCHOOL: Graduate School; HUMSCI: College of Human Sciences; MASS COMM: College of Mass Communication; LAW: College of Law; VPA: College of Visual and performing Arts.

Table 1: Participants' Characteristics.

university loan cap, policies, and regulations.

Students, whose requests for emergency loans were approved are subjected to counseling on the loan guidelines, are advised, and caps are raised to provide more assistance to the students.

Students are required to sign a promissory note in the Student Business Services indicating that they will start paying back the loans in sixty to ninety days at an affordable monthly rate.

The emergency loan borrowed to graduate students has no interest as long as the students abide by all the terms and policies of the promissory note. It should be noted that if the graduate student fails to abide by the terms and policies set by the Students Business Services, then $1 \%$ to $10 \%$ interest is levied.
Each student is encouraged and required to have a dialog about financial planning pre- and post-approval.

Finally, the graduate students must be in good academic standing, and their GPA must be at least 3.00 (Table 1).

The dataset for our study include the following fields for analysis:

a. Loan data

b. Department

c. Loan amount

d. Interest, USD

e. Amount paid

f. Due date

g. Birthday

h. GPA

i. Year entered program

j. Projected graduation date

k. Exit date

1. Degree

m. Age

n. Ethnicity

o. Gender

p. Marital status

q. Degree type

r. College awarded

s. Name, address, phone number, and social security number

t. Students' financial documents

u. Signed emergency loan request with details about the resource dilemma.

The emergency loan approval for all graduate students is based on three fundamental criteria: (1) insurance problems,(2) medical expenses, (3) health problems, (4) total household and family expenses, and (5) teaching and research productivity.

Comments and documentations from students who borrowed emergency loans show that cash shortfalls contribute to emergency loan needs [3-5,17]. Graduate students have a lot of bills to pay such as tuition, fees, housing, food, utilities, rent, etc. Hence, graduate students may not have enough money to address emergency needs relating to health, insurance, automotive, child care, etc. Also, graduate students who are research or teaching assistants do not receive their first pay check until 6 to 8 weeks after their appointments. The emergency loan for addressing emergency needs and for survival over this unpaid period is an inherently better deal compared to using their credit cards over the same unpaid period. Graduate students also seek emergency loans in their last semester before graduation to assist with relocation costs and paying of their first month's rent/utilities before they receive their first paycheck immediately after graduation. Emergency loan payments are scheduled monthly, and there is penalty if the student fails to pay as scheduled. 


\section{Data Analysis}

We implemented data mining techniques (i.e. web graph and generalized linear model) to:

1) Determine the relationships among ethnicity, gender, marital status, degree type, and college awarded

2) Determine the factors that impact GPA and academic performance

\section{Web graph}

Graphs are important source of information [18]; and graphs can be used to represent complex information and data. Graphs can be used to model social network by using edge between two nodes to represent relationship between two individuals/objects/attributes [19]. Wu et al. state that "Formally, a graph $G(V, E)$ is a set of $n$ nodes (represented by $V$ ) connected by a set of $m$ links (represented by $E$ ). The graph can be represented as a symmetric adjacency matrix $a n \times n$ with $a i j=1$ if node $i$ is connected to node $j$ and $a i j=0$ otherwise" (p.314). The software we used in our analysis is IBM SPSS Modeler. The visual results for the web analysis are shown in below in all Figures.

Patterns/Relationships for large emergency loans: It should be noted that the legends in Figure 1 are explained in detailed in Table 1. Figure 1 shows that the two colleges with the most powerful links are the College of Arts and Sciences and College of Engineering. Also, the web graph shows that the College of Arts and Sciences and the College of Engineering borrowed the most emergency loans. From Figure 1, The College of Arts and Sciences has the strongest and thickness links to degree type, ethnicity, gender, and marital status compared to other colleges. The college with the weakest links is the College of Visual and Performing Arts. Figure 1 shows that graduate male students have more links to college awarded, degree type, ethnicity, gender, and marital status compared to female graduate students. Based on the strengths and thickness of the links, there are more singles that are pursuing their masters' program compared to pursuing their $\mathrm{PhD}$. Also, $\mathrm{PhD}$

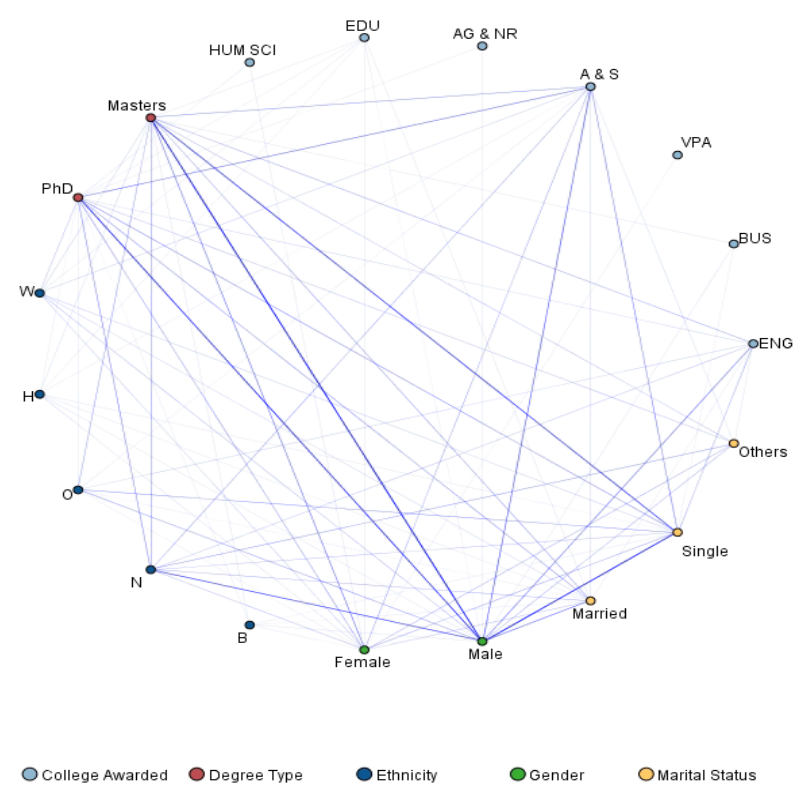

Figure 1: Relationship among College Awarded, Degree Type, Ethnicity, Gender, and Marital Status for large emergency loans.

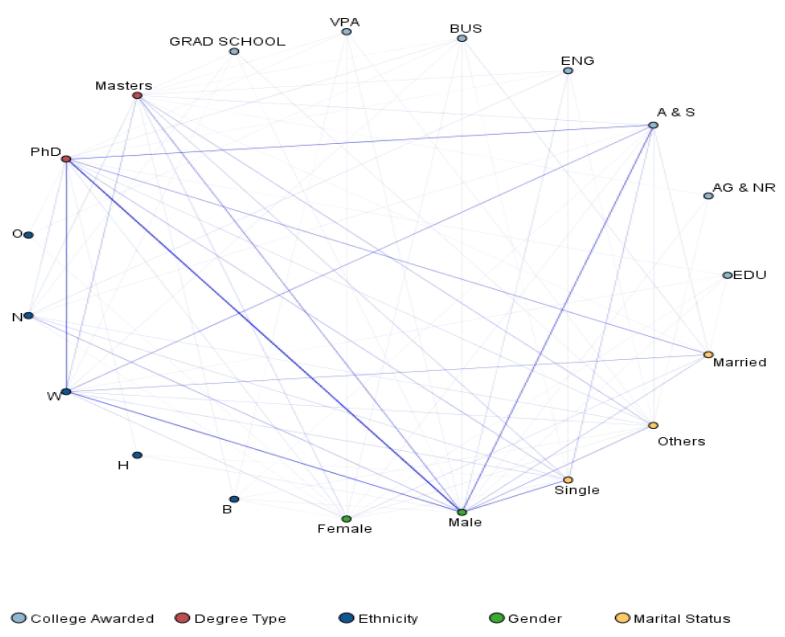

Figure 2: Relationship among College Awarded, Degree Type, Ethnicity, Gender, and Marital Status for small emergency loans.

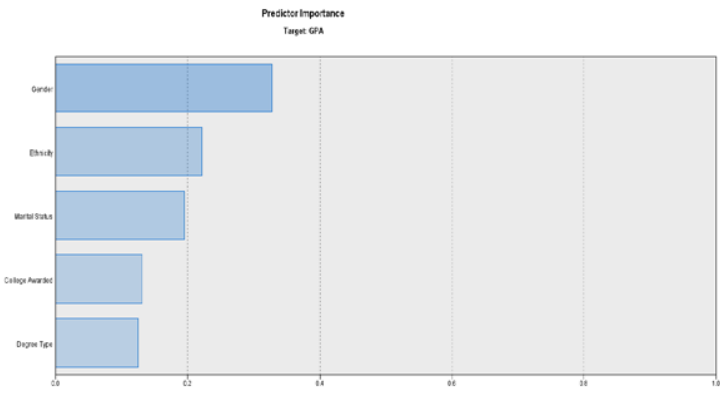

Figure 3: Predictor Importance on GPA

students from the College of Arts and Sciences are borrowing the most emergency loans. Also, Figure 1 shows that non-resident alien (i.e. international students) has more links to degree type, ethnicity, gender, and marital status compared to other ethnicity.

Patterns/Relationships for small emergency loans: The legends in Figure 2 are explained in detailed in Table 1, Figure 2 shows that the college with the most powerful link is the College of Arts and Sciences. Also, Figure 2 shows that the College of Arts and Sciences borrowed the most emergency loans relating to small loans. From Figure 2, The College of Arts and Sciences has the strongest and thickness links to degree type, ethnicity, gender, and marital status compared to other colleges. The college with the weakest links is the College of Agriculture. The web graph (Figure 2) shows that graduate male students have more links to college awarded, degree type, ethnicity, gender, and marital status compared to female graduate students. Based on the strengths and thickness of the links, there are more married graduate who are pursuing their $\mathrm{PhD}$ compared to single graduates. Hence, more married graduate are borrowing a lot of small emergency loans to address family expenses/concerns. Also, PhD students from the College of Arts and Sciences are borrowing the most emergency loans relating to small loans. The web graph (Figure 2) shows that white graduate students borrowed the most relating to small emergency loans. 


\section{Generalized linear model}

Generalized linear model can be used with several explanatory variables and model uncertainty [20]. Hence, we used general linear model in our analysis. Figure 2 shows the predictor importance on GPA.

From Figure 3, the factor that has the most impact on academic GPA is gender; and the factor that has the least impact on academic GPA is degree type. The only two factors that have a significant effect on GPA are (1) gender with a significant of 0.001 ; and (2) degree type with a significant of 0.004 .

\section{Visualization for large loan vs. small loan}

The analysis is a strong indicator, providing clear evidence that emergency loan needs exist in a diverse spectrum of colleges, degree types, ethnicities, genders, ages, and marital statuses. Figure 4 shows that more graduate students' borrowed large amounts of emergency loans compared to small amounts of emergency loans. Idemudia and Ferguson [3,4] argue that emergency loans help students to successfully complete their studies instead of dropping out of school.

College awards for large and small loans: Both Figures 5 and 6 strongly support Idemudia and Ferguson [3,4] studies that the college of arts and sciences borrowed the most loans. Figure 5 show the colleges that are awarded for small loans; the college of arts and

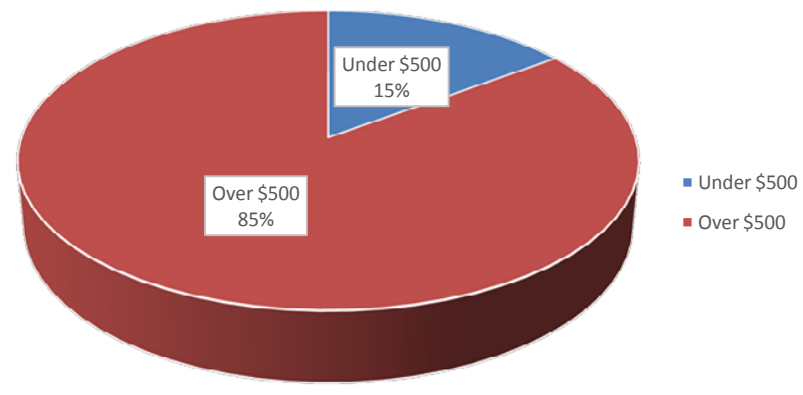

Figure 4: Large Loan vs. Small Loan.

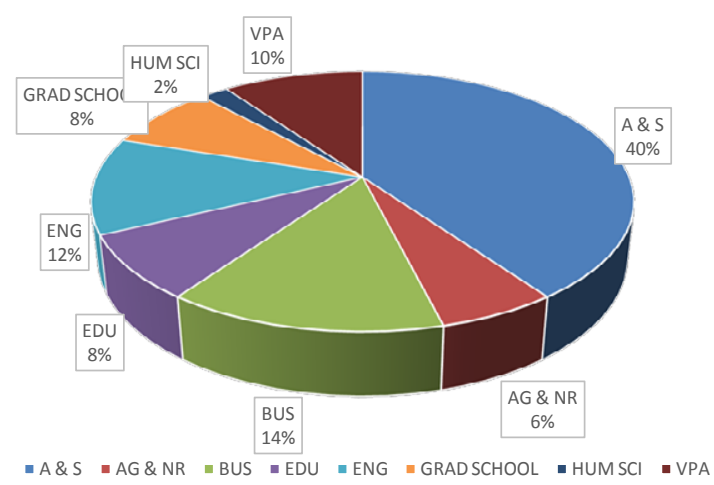

Notes: College legend:

A and S: college of arts and sciences; GRAD SCHOOL: graduate school, $\mathrm{AG}$ and NR: college of agriculture, $\mathrm{HUMSCl}$ : college of human sciences, ARCH: college of architecture, MASS COMM: college of mass communication, BUS: college of business, LAW: college of law;

EDU: college of education, VPA: college of visual and performing arts. ENG: college of engineering.

Figure 5: Colleges Awarded for Small Loans.

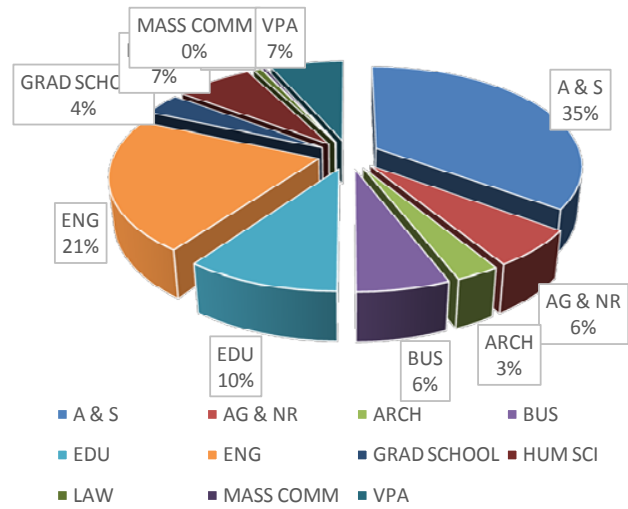

Figure 6: Colleges Awarded for Large Loans.

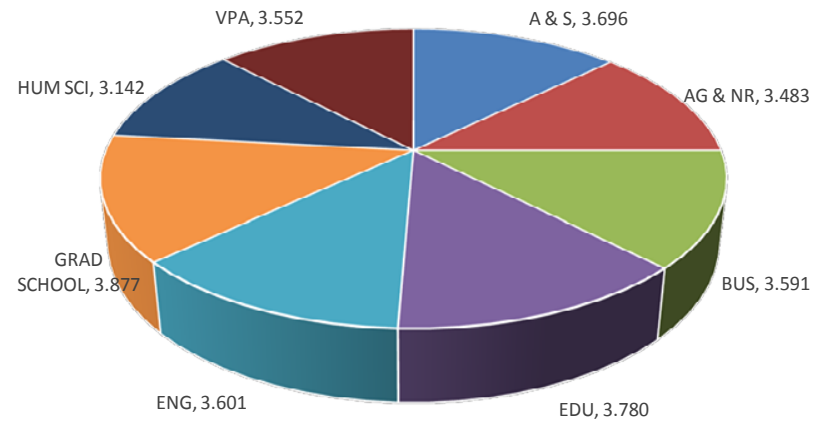

Figure 7: Average GPA and College Awarded for Small Loans.

sciences borrowed the most, while the college of human sciences borrowed the least. Figure shows the colleges that are awarded for large loans; again, the college of arts and sciences borrowed the most. It should be noted that both Figures 5 and 6 shows that the college of law only borrowed loans identified as large. These results provide insights into universities' deans, administrations, and presidents on how to allocate financial resources based on colleges and graduate students' needs. Also, our study opens the doors for future researchers to investigate some of the specific factors and variables that can explain why students from different colleges borrowed both small and large emergency loans. Future researchers should also investigate if there is a relationship between specific colleges and emergency loans. It is clear that debt has a negative influence on students pursuing graduate studies [3-5,17,21]. Doctoral students borrowed more loans compared to other degree types [22]. Every year, due to the constant increase in graduate education, graduate students are anticipating greater emergency loan need to address unplanned and rapidly building cost related to utilities, energy, rent, insurance, food etc. [3-5].

Average GPA and colleges awarded for small and large loans: Figure 7 shows the average GPAand college awarded for small loansthe college of graduate school has the highest GPA, and the college of human sciences has the lowest GPA. For large loans, as shown in Figure 8 , the college of visual and performing arts has the highest GPA, and the college of mass communication has the lowest GPA. These results open the doors for researchers to investigate the specific factors and variables that affect GPA, and knowing these factors provides insight for universities' deans, administrations, and presidents on policies set to enhance academic performance in graduate schools. 


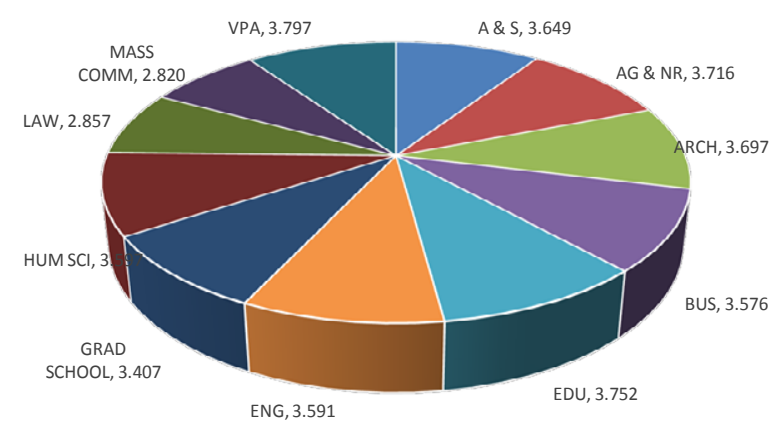

Figure 8: Average GPA and College Awarded for Large Loans.

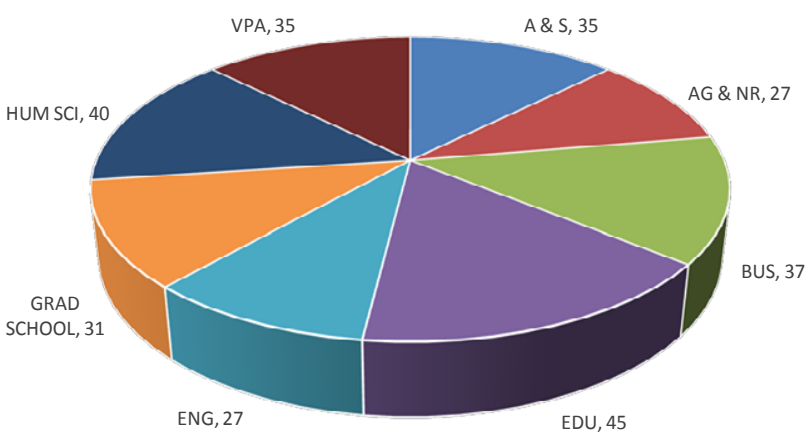

Figure 9: Average Age and College Awarded for Small Loans

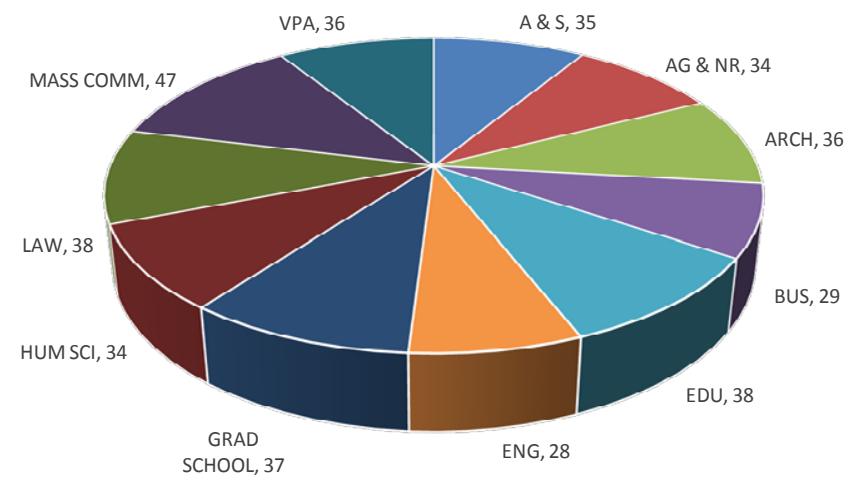

Figure 10: Average Age and College Awarded for Large Loans.

\section{Average age and colleges awarded for small and large loans}

Figure 9 shows the average age and college awarded for small loans-the college of education has the highest average age, and the college of engineering and agriculture has the lowest average age. Figure 10 shows the average age and college awarded for large loansthe top two colleges with the highest average age are the college of mass communication and the college of education, and the lowest is the college of engineering. Figures 9 and 10 show that the college of engineering has the lowest average age. These results open the doors for future researchers to investigate why certain colleges attract younger or older graduate students. This information aids university' deans, administrations, and presidents concerning policies to set in place in order to help graduate students with families while they pursue graduate degrees.

\section{Gender and awards for small and large loans}

Figure 11 shows genders awarded for small loans-male graduate students borrowed the most; it is more than three times the value requested by female graduate students. Figure 12 shows gender and the division for large loans. These results show that female graduate students borrowed large emergency loans compared to small emergency loans. Our study opens the door for future researchers to investigate generally, for both small and large loans, why male graduate students have a greater overall emergency loan need compared to female graduate students. Churaman [23] notesfemale students received more financial aid compared to male students, while males borrowed the most relating to emergency loans $[3,4]$.

\section{Marital status and awards small and large loans}

Figures 13 and 14 reflect that graduate students who are single have the largest amount for both small and large emergency loans. Some of the reasons why graduate students who are single borrowed the most loans are: (1) graduate students who are single do not have spouse to help to support their education, and (2) graduate schools overall have more graduate students who are single. Idemudia and Ferguson $[3,4]$ argue that graduate students who are single borrowed the most of all marital statuses in graduate schools. Our study opens the doors for future researchers to investigate the relationships between other marital statuses and small/large loans.

\section{Degree type and awards for small and large loans}

In our study, the variable, doctorate, includes $\mathrm{PhD}$, JD, and a

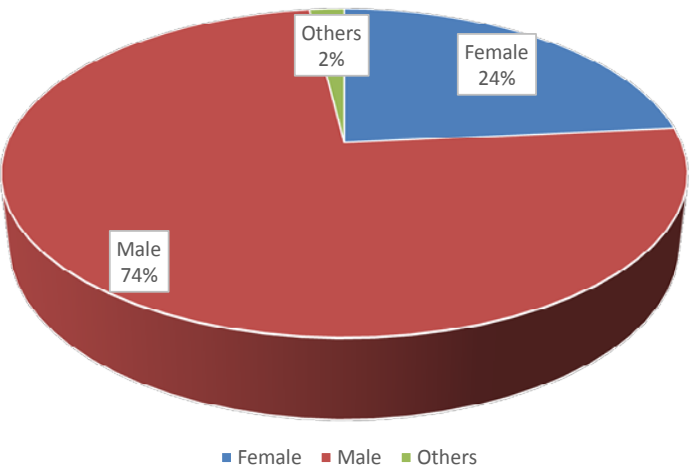

Figure 11: Gender Awarded for Small Loans.

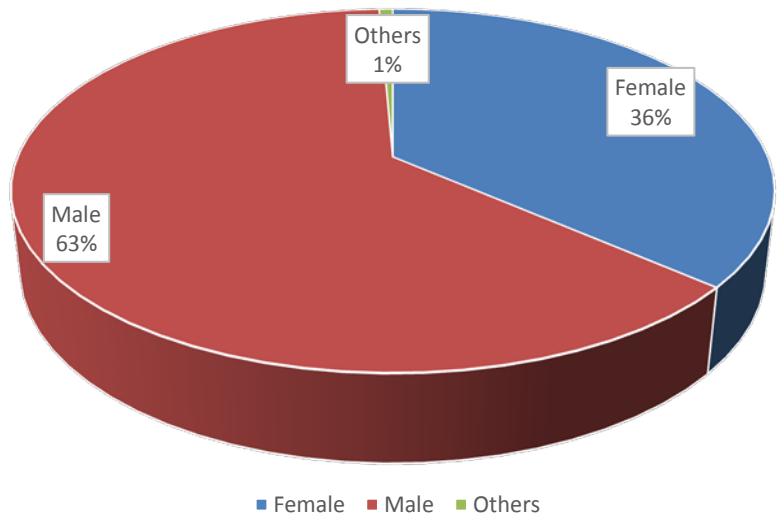

Figure 12: Gender Awarded for Large Loans. 


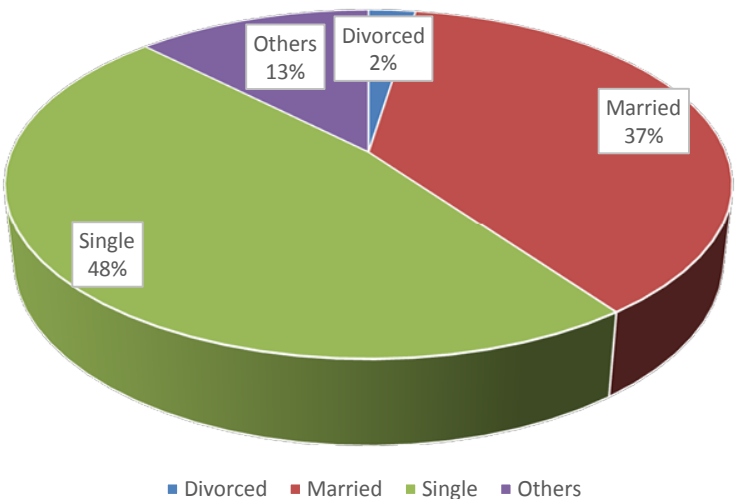

Figure 13: Marital Status Awarded for Small Loans.

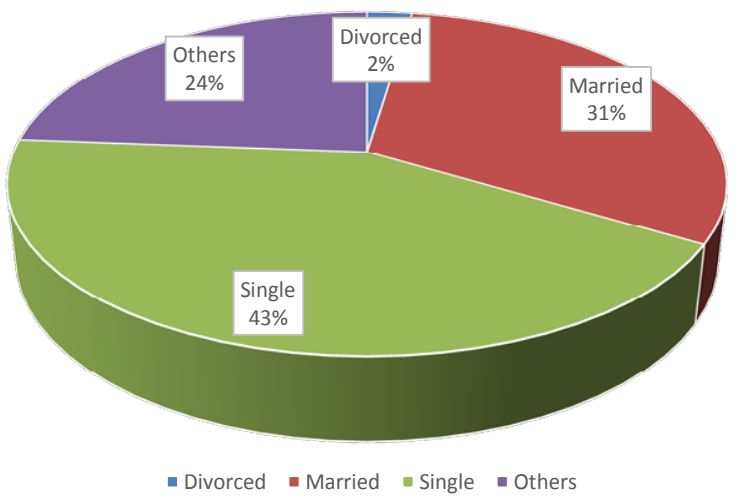

Figure 14: Marital Status Awarded for Large Loans.

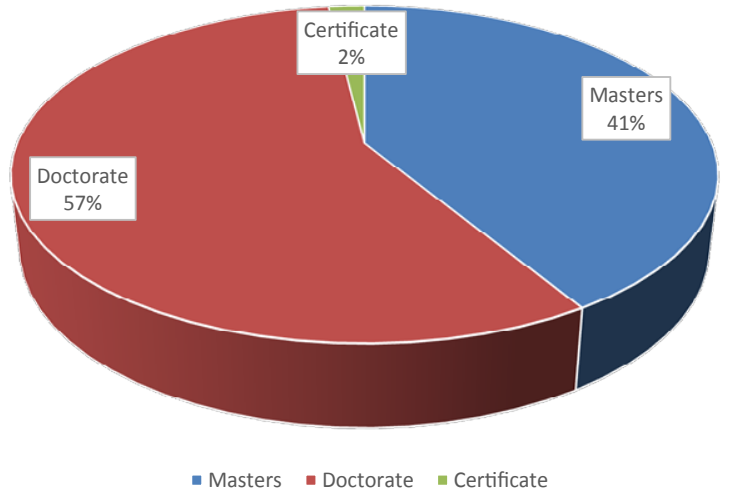

Figure 15: Degree Type Awarded for Small Loans.

doctorate of music. Figure 15 shows degree type awarded for small loans-doctoral degrees have the largest amount of small loans. Figure 16 shows each degree type awarded for large loans-a masters degree has the largest amount of large loans. Idemudia and Ferguson $[3,4]$ argue that masters students borrowed the most emergency loans because there are more masters students in graduate schools compared to doctoral students or certificate students. Both Figures 15 and 16 show that certificate studies have the lowest amount of loan costs [24]. Certificate students are working professionals seeking a certificate/credential that may increase their income, provide a chance

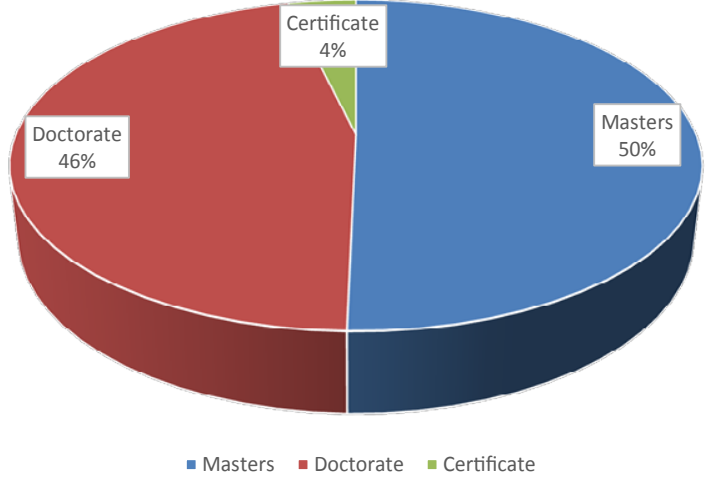

Figure 16: Degree Type Awarded for Large Loans.

for promotion, and improve their standard of living. It should be noted that our study opens the door for future researchers to investigate the possibility of a relationship between degree type and small/large loans.

\section{Conclusion}

University leadership's use of traditional concepts with a twist represents the absence of tenacity required for administrative innovation to engage for a different future in academia. Domestic student loan borrowing exceeds a trillion USD. To increase the number of graduates, emerging nations are trusting the same model may serve to stimulate economic growth in their local markets. Domestic and International students will have debt service responsibilities when they complete their degrees. A more expansive study by researchers may clarify the percentage of economic contraction attributed to debt service due to education borrowers. Emergency loan need signals that there is a prevailing hazard associated with the current model of student loan borrowing. The loan and financial aids theory indicates what borrowers fail to do when burdensome debt consumes a share of their earnings [5]. Debtors must weigh the ethical quotient that the risk-reward of education is too unstable to stay in the university system a sufficient amount of time to overcome their other financial stressors. Though education is intellectually transformative, the notion that it is the key to wealth building generated the education industrial complex which evolved into the belief that a student must achieve an academic credential no matter the cost.

Going forward, U.S. universities must plan decisive strategies to manage three costs: 1) the rising value of the dollar, 2) tuition and fee increases, and 3) increased living expenses. Though there is a rollback in fuel cost and the utility power savings will benefit institutions, prices for students may remain level or creep slowly to a higher sum. The trans-relational value universities must include in their cost structure is dollar averaging, so that low income, underrepresented, and emerging nations' students continue to view education as a life changing function. The wealth gap in the U.S. is inextricably linked to education for underrepresented populations. As an example, Frolich (2014) reports that Black Americans make about 62 cent for every dollar earned by White American. Greater systemic fragmentation may occur as rising cost dissuade fewer domestic and international students to achieve a university education to improve the well-being of their communities. Failure to recognize the emergency loan signal may intersect with a measurable assertive group that may put national civility at risk because it cost regulated their opportunity. Also, it is vital that there is not a significant shrinkage of international students denied 
access to U.S. universities due to affordability. There is a tipping point where education cost slips into a reversal position that stalls progress or increases inclusiveness to a growth positive market's competitiveness for global well-being.

Knowledge is a common interest that is present in every culture. In future studies, researchers from this assessment may weigh the impact of education cost on expanding intellectual capacity among disenfranchised populations. Broadening education opportunities in the U.S. have expanded the economy and increased a more open dialog into diverse cultural communities. This progress momentum is subject to risk without long-term leadership strategies, and the absence of a plan to manage education inclusiveness is unwise as the shift toward a global trans-relational neighborhood continues. Being aware of global activities within seconds brings new meaning for a global intellectual population to resolve natural and/or man-made calamities. This new age lifts the responsibility of university leadership with governments to avoid forfeiting the momentum of the learning community.

\section{References}

1. Korn M (2015) Study finds wealth gap in graduation rates. The Wall Street Journal.

2. Frohlich TC (2014) The worst states for black Americans.

3. Idemudia EC, Ferguson R (2014a) An Empirical Investigation of domestic and international Graduate Students with Emergency Loan Need Signals Global Challenge of Managing the Cost of U.S. Education. International Journal of Education Economics and Development 5: 319-331.

4. Idemudia EC, Ferguson R (2014b) Emergency Loan Need Among Graduate Students Signals Debt Trends in Higher Education May Influence the Expansion of the U.S. Economy Long-term. Journal of Business Administration and Education 5: 79-98.

5. Idemudia EC, Ferguson R (2015) Trans-relational Ethics: Emergency Loan Need May Influence the Availability of Graduate Students in Global Research and Business. SAM International Business Conference, Las Vegas, Nevada, USA.

6. Korn M (2014) Tuition trails inflation for many u.s. colleges. The Wall Stree Journal.

7. Mangan K (2014) Colleges saw a flood of students at recession's peak-and discouraging results. The Chronicle of Higher Education.
8. Lang DW (1999) A primer on responsibility centre budgeting and responsibility centre management. CSSHE (Canadian Society for the Study of Higher Education).

9. Welitzkin P (2014) Chinese applications for US grad schools decline

10. Yue Z (2014) Job hunt especially critical for graduates with student loans China Daily.

11. Dore B (2011) Less than $10 \%$ Indians take student loans: report. Hindustan Times.

12. McMahon D (2014) In china, loan ties spread the misery. The Wall Street Journal.

13. Swarup AG (2013) Financing your education with Indian student education loans.

14. Supiano B (2014) Forget rise in tuition and fees, what about living expenses? The Chronicle of Higher Education.

15. Friedman N (2014) Dollar's rise is pain abroad. The Wall Street Journal.

16. Jamrisko M, Kolet I (2014) Cost of college degree in u.s. soars 12 fold: chart of the day.

17. Idemudia EC, Ferguson R, Ferguson D (2013) An Empirical Analysis of Emergency Student Loan Need Signals International Graduate Student may Face an Affordability Challenge Attending U.S. Graduate Schools. Journal of Business Administration Online.

18. Rahal I, Ren D, Wu W, Denton A, Besemann, et al. (2006) Exploiting edge semantics in citation graphs using efficient, vertical ARM. Knowledge and Information Systems 10: 57-91.

19. Wu L, Wu X, Lu A, Zhou Z (2013) A spectral approach to detecting subtle anomalies in graphs. Journal of Intelligent Information Systems 41: 313-337.

20. Woods DC, Lewis SM, Eccleston JA, Russell KG (2006) Designs for generalized linear models with several variables and model uncertainty. Technometrics 48 : 284-292.

21. Healy G (2009) Overseas students defy downturn to come to Australia.

22. Schuman J (2005) Student borrowing has increased sharply since 1992, report says. The Chronicle of Higher Education.

23. Churaman CV (1992) Financing of college education by single-parent and twoparent families. Journal of Family and Economic Issues 13: 95-112.

24. Idemudia EC, Ferguson R (2011) An empirical analysis that forecast a high likelihood of emergency loan need between ages 27 to 41 among graduate students for policy decisions. International Journal of Education Administration and Policy Studies 3: 112-116. 